Tetiana Popova,

Doctor of Philological Sciences (Dr. habil. in Philology), Professor of Department of Literature and Russian Language, Northern Arctic Federal University

(Severodvinsk, Russia)

ORCID 0000-0002-8431-2962

ResearcherID P-2962-2015

ScopusID 57191748750

SPIN-cod 3254-7740

e-mail: lestvic@mail.ru

\title{
"THE SIBERIAN LADDER" IN SLAVONIC WRITING
}

The aim of the research. The aim of the research is to draw specialists' attention to the manuscripts of the monument of Slavic literature of the 17th century, known in science as the "Siberian Ladder", the author of which is traditionally considered to be the Siberian Metropolitan Filofey Leshchinsky. The methodology of the study. The main research method is the linguistic-textological method of analyzing manuscripts. In addition, descriptive and statistical methods of material analysis are used in the research. The scientific novelty. The article is the first to express the hypothesis that the author of the "Siberian Ladder" book may be a monk who lived at the end of the 17th century in one of the Kyiv monasteries, since the oldest manuscripts of the monument were in use in Kyiv. A systematized updated information on the corpus of manuscripts with the text of "Siberian Ladder" is given. A chronological list of codes with the text of the monument is attached to the article. A total of 32 manuscripts with the text are named. This list includes 4 books, the fate of which is unknown, with the aim of the possible discovery of these manuscripts in the future. 14 of the 28 books that have survived nowadays are kept in the collections of the Institute of Manuscript of the Library of the Academy of Sciences of Ukraine: in the collection of the Kyiv-Pechersk Lavra (10), in the collection of Saint Sophia Cathedral (2), in the collection of Kyiv Spiritual Academy (1) and in the collection of Mykolaivskyi monastery (1). In addition, manuscripts with the text of the "Siberian Ladder" are in the collections of Russia (5), Romania (4), Greece (3), Lithuania (1) and Belarus (1). Conclusions. It is necessary to carry out a thorough comprehensive historical and philological analysis of the oldest Kyiv manuscripts with the text of the "Siberian Ladder". As a result of this analysis, the hypothesis stated in the article about the creation of a book in a Kyiv monastery by one of the monks of this monastery may be confirmed (perhaps the name of this monk will also be found). In this case, the opinion established in science that the author of the work was Metropolitan Filofey Leshchinsky can be debunked. On the other hand, it is necessary to study the biography of Filofey Leshchinsky (the Kyiv period of his life) carefully. As a result of this analysis, the hypothesis that the "Siberian Ladder" belongs to Metropolitan Filofey may be confirmed.

Key words: "Siberian Ladder", Filofey Leshchinsky, "Ladder" of John Climacus, manuscript collections, Old Russian literature. 
Relevance of the research topic. "The Siberian Ladder" is a poorly studied monument of ancient Russian literature. It became widespread in the Kiev lands. It was probably created in one of the monasteries in Kiev at the late $17^{\text {th }}$ century. The Siberian Metropolitan Filofey (Leshchinsky) is considered to be its author. However, perhaps it is a mistake going back to the authors of the description of the manuscripts of the Synodal collection of the State Historical Museum A.V. Gorskij and K.I. Nevostruev. Early "Siberian Ladder" manuscript is kept in the collections of Kiev. A thorough, comprehensive historical and philological analysis of these manuscripts will help answer the question whether Filofey was the author of the "Siberian Ladder".

Analysis of research and publications. There are no studies of the "Siberian Ladder" as a literary monument. There are only descriptions of its manuscripts in different collections of libraries in 6 countries of the world. The location of 28 manuscripts is known. The destiny of 4 manuscripts is unknown. In 2015 in Tyumen was published the text of "Siberian Ladder". No preliminary analysis of the manuscript tradition of the monument has been carried out. Therefore, this edition contains many different errors.

The aim of the research. The aim of the research is to draw specialists' attention to the manuscripts of the monument of Slavic literature of the 17th century, known in science as the "Siberian Ladder", the author of which is traditionally considered to be the Siberian Metropolitan Filofey Leshchinsky.

Main body of the paper. In 2015 the Tyumen Publishing House "Russkaja nedelja" published the book "Saint Filofey Leshchinsky. The Siberian Ladder" [13]. This edition is a "translation" (from Russian $18^{\text {th }}$ into Modern Russian) performed by M. Bakulin and T. Sayfullin. The "translation" was carried out from the manuscript No. 120 from the collection of the Holy Synod; kept in the State Historical Museum (Moscow). The annotation to this publication states that the manuscript is a "unique", "the only and possibly the last copy" of the "Siberian Ladder", "discovered" by the named "translators" in the State Historical Museum "only in 2015". The publication received high praise in the local press. It was presented to the general public and university professors. S. Arutyunov published the positive review to this book in the journal "Literaturnaja Rossija" (10.02.2017, No. 5)' . This edition was among the winners of the competition for the best book. In 2016 this book received the prize of the Publishing Council of the Russian Orthodox Church².

Such ignorance of many people related to the release and promotion of this book is puzzling and outrageous. Firstly, a multivolume classical description performed by A.V. Gorskij and K.I. Nevostruyev is devoted to the manuscripts of the Collection of

\footnotetext{
${ }^{1}$ URL: http://litrossia.ru/item/9705-trjokhsotletnij-poet/.

${ }^{2}$ URL: http://izdatsovet.ru/news/detail.php?ID=177527\&PAGE_NAME=section\&SECTION_ID=1230.
} 
the Holy Synod of the State Historical Museum, and the manuscript No. 120 with the "Siberian Ladder" was discovered and brought into the scientific circulation by them a long time ago [6, pp. 266-280]. Their work attracted repeatedly the attention of many researchers, however, it remained unknown to the persons involved in the publication of "The Siberian Ladder" (Tyumen, 2015) and to the persons presenting awards to this publication. Secondly, this manuscript is far away from being the "the only one" or the "last" book of the "Siberian Ladder". Up to our time dozens of manuscripts with the text of this work have survived. One of them is a book in the Synod collection of manuscripts of the State Historical Museum. There is an autographic note of Dmitri Rostovsky in this manuscript. He wrote that this book was sent to him from Filofey Sibirskiy on March 1705. Thus, Filofey presented one copy of this book to Dmitri Rostovsky. However, the publishers M. Bakulin and T. Sayfullin mistakenly write that they are publishing Filofey's autograph.

I expressed my confusion and questions related to this publication in an article published in Novosibirsk in 2018 [10]. In 2019 a review of this edition was published in St. Petersburg, containing its critical analysis [7]. The authors of the review concluded the book does not meet modern requirements for scientific publications and contains numerous errors and mistakes.

The tasks of this article are a brief description of the handwritten tradition of this book and an indication of the storage sites for the surviving manuscripts of the "Siberian Ladder".

The basis for the "Siberian Ladder" is one of the most popular books of the Christians in the Middle Ages: "The Ladder of Divine Ascent", here shortly the "Ladder". This extensive treatise about monastic life was written by the abbot John of the Sinai monastery of St. Catherine at the beginning of the $7^{\text {th }}$ century. The book was written in Greek. The bright symbolical image of this book is the image of a ladder conducting to the sky. The author calls the chapters of the book "steps". Step by step a person comes nearer to paradise. The quantity of steps of this ladder is 30 , because Jesus Christ lived 30 years.

It is unknown which title gave the author to his book. The original of the "Ladder" was not kept. Medieval scribes copied this book very often. The quantity of Greek manuscripts of this book is huge. I know that today about 766 Greek manuscripts exist with the text of the "Ladder" [4]. Not less than 10 different Greek names of the book were kept. These various names were given to the book by copyists.

Already in the middle of the $7^{\text {th }}$ century the book was translated into the Syrian language. In medieval times the book was also translated into Arabic, Georgian, Ethiopian, Dutch and Portuguese. Furthermore the "Ladder" was translated many times into Armenian, Latin, Italian, Spanish, French, Roumanian and Slavonic languages. 
In the Middle Ages the book became popular especially among the Slavonic readers. I know 1066 old Slavonic manuscripts [3]. Among these manuscripts are 5 ancient Slavonic translations of the book. The majority of these books is written in Russian. In the Slavonic manuscripts the book is usually called "Lestvica" (this word is the old version of the word "lestnica" = "ladder"). In Russia the author of the book, John Climacus, was called John Lestvichnik (Иоанн Лествичник). This name - Lestvichnik - was partially transferred on the name of his book, too. Thus, in the Russian manuscripts "The Ladder of Divine Ascent" can be called both "Lestvica" and "Lestvichnik".

In 1647 in Moscow, in the Synod printing house, the first Russian printed edition of Lestvica was issued with 1200 copies. So the book became more available to the Russian readers. Hand-written copies of this edition had a wide spreading in Russia.

In the $18^{\text {th }}$ century the book was widely extended in the Slavonic writing under the name "The Siberian Ladder" («Сибирский Лествичник»). This is not a translation of the "Ladder", but its free creative reworking. The author of the "Siberian Ladder", according to A.V. Gorskij and K.I. Nevostruev, was the well-known educator of Siberia, metropolitan Filofey Leshchinsky [6, p. 266]. They made this assumption because there were two pieces of paper glued to one of the books, on which is to read "Filofey the Bishop" («Филофей архиерей») and "The Siberian Ladder" («Сибирский Лествичник»). A.V. Gorskij and K.I. Nevostruev suggested that the author of this work is Filofey. This opinion about the authorship of Filofey is widespread in science; it is included in the fundamental and for researchers very important book «The Dictionary of Scribes and Bookishness of Ancient Rus'" [12, p. 257]. Following these scientists, I also used the combination "The Siberian Ladder of Filofey Leshchinsky" in my publications $[8$, p. $61-62 ; 10]$. But the reference of the literature monument to the authorship of Filofey, established in science, led to great objections by the authors of the review of the edition of the "Siberian Ladder" [7].

Filofey Leshchinsky was born in Ukraine in 1650 in a noble family. He was a student in the Kiev spiritual academy. Then he married. After his wife died he decided to become a monk of Kievo-Pecherskaja lavra. In 1701 Filofey Leshchinsky was appointed to the deputy of the Bryansk Svensky monastery. At the same time a chair of Siberia and Tobolsk became vacant. The Emperor Peter the Great directed the metropolitan to take the well-known church writer Dimitrii Tuptalo. However Dimitrii was ill, and that's why he didn't leave Siberia but went to Rostov. So we know him as Dimitrii Rostovsky. Therefore Peter the Great ordered the Kiev metropolitan to find a clever and pious person for this position. The choice was Filofey Leshchinsky.

On January 1702 Filofey became metropolitan of Siberia and Tobolsk. His diocese was huge, from the Arctic Ocean to China and from the Ural Mountains to Kamchatka. Dimitrii Rostovsky ordained him. 
Metropolitan Filofey Leshchinsky was an outstanding church figure. He did a lot to educate Siberia. However, there are no historical facts testifying to his literary talent and his activities as a writer. Therefore, the question about the authorship of the book "The Siberian Ladder" remains open.

If the hypothesis of A.V. Gorskij and K.I. Nevostruev is correct, Filofey wrote the book (the name of this book is unknown) at the end of the $17^{\text {th }}$ century in KievoPecherskaja lavra. If their hypothesis is incorrect, the author of the book may be a monk of one of the Kiev monasteries (very likely of Kievo-Pecherskaja lavra). The oldest manuscript of the book is kept in Kiev and dates from the late $17^{\text {th }}$ century. Later this literary monument in honor of the Siberian Metropolitan received the title "The Siberian Ladder".

The basis for "The Siberian Ladder" is the Moscow edition of the "Ladder". It is its free interpretation. The author of "The Siberian Ladder" transferred the book ("Ladder" of John Climacus) by his own words, deleted some fragments of the text, added some new ones and interpreted them. He added his own reflections to the text of the "Ladder", commented and excerpted patristic literature from church [6, p. 279]. Thus, 30 chapters of Ladder were transformed to 70 chapters of "The Siberian Ladder". For example, the author divided one story (about obedience) into ten independent semantic fragments - ten stories. In some passages he reduced this story and in other ones he added his own reasoning, extracts from Paterikon, fragments from the life of Saint Antonii, Saint Moisii and Saint Makarii, furthermore extracts from the book of Nikon from Black Mountain.

For today I know about 32 hand-written books of "Siberian Ladder" written during the period from the end of the $17^{\text {th }}$ to the end of the $18^{\text {th }}$ century.

From these 32 manuscripts only 8 books have an exact dating. Other manuscripts are dated approximately by authors of library inventories. Some of these books weren't exposed to a scientific analysis. Many of them have losses.

The earliest book of "Siberian Ladder" is dated to the late $17^{\text {th }}$ century. There is neither a beginning nor an end in the book. It is stored in Kiev, in the Vernadsky National Library of Ukraine.

I don't know manuscripts of "Siberian Ladder" written after the $18^{\text {th }}$ century.

Manuscripts of "Siberian Ladder" are stored in 16 libraries of 6 countries of the world. 14 books are in Kiev, in collections of the Vernadsky National Library of Ukraine. 5 manuscripts are present in libraries of Russia (in the Russian National Library, in the Russian State Historical Archive, in the State Historical Museum and in the Russian State Library). 4 books are present in Romania (in the Library of the Romanian Academy of Sciences and in the Putna monastery). Manuscripts of "Siberian Ladder" are also on Athos: in the Hilandar monastery, in the Zograf monastery and in the lliinsky monastery. There is one book in the National Library of Lithuania and one book in 
the National Museum of Republic of Belarus. The location of 3 books is not clear. The manuscripts which are stored in monasteries of Romania and Athos are almost inaccessible to research.

Low-study of "Siberian Ladder" has two reasons: 1) many storage places of its manuscripts, 2) inaccessibility of some manuscripts.

Manuscripts of "Siberian Ladder" were in use mainly in the Kiev lands. Exactly there, in Ukraine, the book received the widest circulation. I don't know any manuscript of "Siberian Ladder" which was in use in the territory of Siberia.

The "Siberian Ladder" was the first book rewritten by Peter (Paisius) Velichkovsky. Around 1740, in the Lyubech monastery, Paisius for the first time received the task in rewriting a book - this was the Ladder of St. John Climacus, which became one of the favorite books of the venerable forever. In his autobiography, Saint Paisius wrote that the abbot of the monastery of Onuphrius the Great "once gave me a book of the reverend father of our Father John Climacus, located on seventy teachings" [9].

Reliable sources allow to state, that manuscripts of "Siberian Ladder" were wellknown in the Volga region, in the Nizhniy Novgorod diocese, namely in Sarovskaya pustyn' and Florishcheva pustyn'.

There is one book from Sarovskaya pustyn' in the Russian State Library now.

One manuscript of "Siberian Ladder" was in Florishcheva pustyn'. This book was seen by the well-known Russian scientist A.E. Viktorov, who visited Florishcheva pustyn' [5, p. 232]. In his description of the library of Florishcheva pustyn' the scientist wrote about the manuscript of "Siberian Ladder", which was written in 1784 by the monk Gerasim. In this manuscript there was a miniature with an image of St. John Climacus. Now the location of this manuscript is unknown. Florishcheva pustyn' was closed in 1923, but books from the library of this monastery have vanished earlier. So, for example, the scientist Viktorov wrote in the same description of manuscripts about a book of "Lestvica" from the $16^{\text {th }}$ century. This book was perfectly decorated with gold and had many pictures. It came to the American collector W. Spencer. In 1912 W. Spencer was lost on "Titanic". His collection was bought by the Public Library of New York. There is one manuscript from Florishcheva pustyn' in New York now [2, pp. 10-11]. It is possible to assume, that the book of "Siberian Ladder" came to any collector, too. Thus, there is a hope of its future detection.

I know one more manuscript of "Siberian Ladder", whose destiny isn't clear. In a manuscript, which is stored in the Library of the Romanian Academy of Sciences (cod. 583), there is a record, testifying that the original of this book was a manuscript written in 1707 in Kitaevsky monastery near Kiev. Thus, this fact confirms once again the big popularity of "Siberian Ladder" in the Ukrainian lands at the beginning of the $18^{\text {th }}$ century. This popularity may be connected to the person of the possible author of the book - Filofey Leshchinsky.

\section{Розділ 1}


This is a chronological List of the Manuscripts of "The Siberian Ladder":

1. Cod. Petrov 150. Ukraine, Kiev, Vernadsky National Library of Ukraine, collection of Saint Sophia Cathedral. Late $17^{\text {th }}$ c. (№379)'

2. Cod. Petrov 147. Ukraine, Kiev, Vernadsky National Library of Ukraine, collection of Kiev Spiritual Academy. Late $17^{\text {th }}$ C. - early $18^{\text {th }}$ C. (№398).

3. Cod. Petrov 148. Ukraine, Kiev, Vernadsky National Library of Ukraine, collection of Saint Sophia Cathedral. Late $17^{\text {th }}$ c. - early $18^{\text {th }}$ c. (№399).

4. Cod. Petrov 246. Ukraine, Kiev, Vernadsky National Library of Ukraine, collection of Kyiv Pechersk Lavra. Early $18^{\text {th }}$ c. (№402).

5. Cod. Petrov 247. Ukraine, Kiev, Vernadsky National Library of Ukraine, collection of Kyiv Pechersk Lavra. Early $18^{\text {th }}$ c. (№403).

6. Cod. Petrov 248. Ukraine, Kiev, Vernadsky National Library of Ukraine, collection of Kyiv Pechersk Lavra. Early $18^{\text {th }}$ c. (№404).

7. Cod. Petrov 249. Ukraine, Kiev, Vernadsky National Library of Ukraine, collection of Kyiv Pechersk Lavra. Early $18^{\text {th }}$ c. (№405).

8. Cod. Petrov 250. Ukraine, Kiev, Vernadsky National Library of Ukraine, collection of Kyiv Pechersk Lavra. Early $18^{\text {th }}$ c. (№411).

9. Cod. 509. Belarus, Minsk, National Museum of Republic of Belarus. Early $18^{\text {th }} \mathrm{C}$. (№406).

10. Cod. 5. Greece, Athos, Iliynskii monastery. Early $18^{\text {th }}$ c. (№409).

11. Cod. 158. Russia, St. Petersburg, Russian National Library, collection of P.N. Tikhanov. Early $18^{\text {th }}$ c. (№410).

12. Cod. 120. Russia, Moscow, State Historical Museum, collection of Synod. Before 1705, (№412).

13. Destiny is unknown. Written in Kitaevsky monastery in 1707. Not in the catalog. [1, p. 440].

14. Cod. Petrov 558. Ukraine, Kiev, Vernadsky National Library of Ukraine, collection of Nikolaevsky monastery. 1723. (№414).

15. Cod. 64. Romania, monastery Putna. 1726. (№415).

16. Destiny is unknown. Was in the Lyubech monastery in 1740. Not in the catalog. [11, p. 56].

17. Destiny is unknown. Scriber - Paisius Velichkovsky. Was in the Lyubech monastery. 1740. (№555).

18. Cod. 3994. Russia, St. Petersburg, Russian State Historical Archive, collection of Synod. Before 1744. (№417).

${ }^{1}$ Hereinafter, is indicated the number of the book in the catalog of the Slavonic manuscripts of the "Ladder": Popova, T.G. Die "Leiter zum Paradies" des Johannes Klimakos. Katalog der slavischen Handschriften. Köln - Weimar - Wien:Boehlau-Verlag, 2012. The catalog conteins archeographic information about the manuscripts and bibliography. 
19. Cod. Petrov 244. Ukraine, Kiev, Vernadsky National Library of Ukraine, collection of Kyiv Pechersk Lavra. First half $18^{\text {th }}$ c. (№418).

20. Cod. Petrov 245. Ukraine, Kiev, Vernadsky National Library of Ukraine, collection of Kyiv Pechersk Lavra. First half $18^{\text {th }}$ c. (№419).

21. Cod. 195. Greece, Athos, Zograf monastery. 1762. (№427).

22. Cod. 93. Russia, Moscow, Russian State Library, collection of Sarovskaja pustyn'. 1762. (№428).

23. Cod. Petrov 252. Ukraine, Kiev, Vernadsky National Library of Ukraine, collection of Kyiv Pechersk Lavra. 1766. (№429).

24. Cod. 248. Lithuania, Vilnius, National Library of Lithuania. Second third $18^{\text {th }} \mathrm{C}$. (№459).

25. Cod. 211. Greece, Athos, Chilandar monastery. 1782. (№439).

26. Destiny is unknown. Written in Florishcheva pustyn', scriber monk Gerasim. 1784. (№558).

27. Cod. 595. Romania, Bucharest, Library of the Romanian Academy of Sciences. 1798. (№446).

28. Cod. 583. Romania, Bucharest, Library of the Romanian Academy of Sciences. Late $18^{\text {th }}$ C. (№458).

29. Cod. 566. Romania, Bucharest, Library of the Romanian Academy of Sciences. $18^{\text {th }}$ c. (№465).

30. Cod. Petrov 251. Ukraine, Kiev, Vernadsky National Library of Ukraine, collection of Kyiv Pechersk Lavra. $18^{\text {th }}$ c. (№470).

31. Cod. Petrov 253. Ukraine, Kiev, Vernadsky National Library of Ukraine, collection of Kyiv Pechersk Lavra. $18^{\text {th }}$ c. (№471).

32. Cod. O.I.87. Russia, St. Petersburg, Russian National Library. $18^{\text {th }}$ C. (№473).

So, the name "Siberian Ladder" isn't connected with a place of writing or existing of the book. Such name, probably, was given by copyists (or readers) of the book in honor to the Siberian metropolitan Filofey, who had a huge authority in the territories of Russia and Ukraine. The manuscript donated to Dmitri Rostovsky from Filofey Leshchinsky in 1705 is not the "only one" and not the "last" book of the "Siberian Ladder", as the publishers of this manuscript incorrectly believe.

The scientific novelty. The article is the first to express the hypothesis that the author of the book "Siberian Ladder" may be a monk who lived at the end of the 17th century in one of the Kiev monasteries, since the oldest manuscripts of the monument were in use in Kiev. A systematized updated information on the corpus of manuscripts with the text of "Siberian Ladder" is given. A chronological list of codes with the text of the monument is attached to the article. A total of 32 manuscripts with the text are named. This list includes 4 books, the fate of which is unknown, with the

\section{Розділ 1}


aim of the possible discovery of these manuscripts in the future. 14 of the 28 books that have survived nowadays are kept in the collections of the Institute of Manuscripts of the Library of the Academy of Sciences of Ukraine: in the collection of the Kyiv Pechersk Lavra (10), in the collection of Saint Sophia Cathedral (2), in the collection of Kiev Spiritual Academy (1) and in the collection of Nikolaevsky monastery (1). In addition, manuscripts with the text of the "Siberian Ladder" are in the collections of Russia (5), Romania (4), Greece (3), Lithuania (1) and Belarus (1).

Conclusions. It is necessary to carry out a thorough comprehensive historical and philological analysis of the oldest Kiev manuscripts with the text of the "Siberian Ladder". As a result of this analysis, the hypothesis stated in the article about the creation of a book in a Kiev monastery by one of the monks of this monastery may be confirmed (perhaps the name of this monk will also be found). In this case, the opinion established in science that the author of the work was Metropolitan Filofey Leshchinsky can be debunked. On the other hand, it is necessary to study the biography of Filofey Leshchinsky (the Kiev period of his life) carefully. As a result of this analysis, the hypothesis that the "Siberian Ladder" belongs to Metropolitan Filofey may be confirmed.

\section{Список використаних джерел}

1. Panaitescu P. P. Catalogul manuscriselor slavo-române şi slave din Biblioteca Academiei Române. Vol. II. (№ 301-600). Bucureşti, 2003. 515 p.

2. Parpulov G. R. Cyrillic Manuscripts in U.S. Public Collections: A Catalogue. Palaeoslavica. 2010. T. 17 (2). P. 1-53.

3. Popova T. G. Die "Leiter zum Paradies" des Johannes Klimakos. Katalog der slavischen Handschriften. Köln - Weimar - Wien: Boehlau-Verlag, 2012. 1037 p. URL: https://doi. org/10.31651/2413-8142-2020-24-Orlyk-Pavlenko

4. Popova T. G. The Greek Manuscripts with the Text of the Ladder of Saint John Climacus: a Preliminary Skeleton List. Aachen: Shaker Verlag, 2018. 78 p.

5. Викторов А. Е. Описи рукописных собраний в книгохранилищах Северной России. Издание Археографической комиссии. С.-Петербург, 1890. 378 с.

6. Горский А. В., Невоструев К. И. Описание славянских рукописей Московской Синодальной (патриаршей) библиотеки. Отд. ІІ. Писания святых отцов. Ч. 3. Разные богословские сочинения (прибавление). Москва: Синодальная типография, 1862. 687 с.

7. Дергачёва-Скоп Е. И., Соболева Л. С. Маленькая заметка о большом недоразумении, или Был ли св. Филофей (Лещинский) автором «Сибирского Лествичника»? // Петербургские славянские и балканские исследования. 2019. № 1 (25). С. 193200. DOl: https://doi.org/10.21638/11701/spbu19.2019.114

8. Попова Т. Г. Киевские рукописи Лествицы Иоанна Синайского // Рукописна та книжкова спадщина України. 2019. Вип. 23. С. 56-71. D0l: https://doi.org/10.15407/rksu.23.056 
9. Попова Т. Г. Лествица Иоанна Синайского в переводе Паисия Величковского // Афонська спадщина. Науковий альманах. Видання Міжнародного інституту афонської спадщини в Україні. Київ-Чернігів, 2016. Вип. 3-4. С. 186-196.

10. Попова Т. Г. Сибирский Лествичник Филофея Лещинского и его рукописи // Рукописи, старопечатные и редкие книги в собраниях России: сб. науч. ст. Новосибирск : ГПНТБ СО РАН, 2018. С. 115-128.

11. Преподобный Паисий Величковский. Житие и избранные творения / Церковнославянский текст с параллельным русским переводом А. П. Власюка. Серпухов, 2014. 560 c.

12. Прохоров Г. М. «Лествица»: Словарь книжников и книжности Древней Руси // ТОДРЛ. Т. XXXIX. Ленинград : Наука, 1985. С. 253-258.

13. Святитель Филофей Лещинский. Сибирский Лествичник. Изд. М. Бакулин, Т. Сайфуллин. Тюмень : Русская неделя, Тюменский издательский дом, 2015.560 с.

\section{Тетяна Георгіївна Попова,}

доктор філологічних наук, професор кафедри літератури та російської мови, Північний (Арктичний) федеральний університет

(Северодвінськ, Російська Федерація) ORCID 0000-0002-8431-2962

ResearcherID P-2962-2015

ScopusID 57191748750

SPIN-cod 3254-7740

e-mail: lestvic@mail.ru

\section{«Сибірський Ліствичник» у слов'янській писемності}

Мета роботи. Метою роботи $\epsilon$ привернення уваги фахівців до рукописів пам'ятника слов'янської літератури XVII ст., відомого в науці як «Сибірський Ліствичник», автором якого, за традицією, прийнято вважати сибірського митрополита Філофея Лещинського. Методологія. Основним методом дослідження $\epsilon$ лінгвотекстологічний метод аналізу рукописів. Крім того, в роботі застосовуються описовий та статистичний методи аналізу матеріалу. Наукова новизна. У статті вперше висловлюється гіпотеза про те, що автором книги «Сибірський Ліствичник» може бути ченець, який жив наприкінці XVII ст. в одному з київських монастирів, оскільки найдавніші рукописи пам'ятника побутували в Києві. Наводиться систематизована уточнена інформація про корпус рукописів з текстом «Сибірського Ліствичника». До статті додається хронологічний список кодексів з текстом пам'ятника. Всього називається 32 рукописи з текстом «Сибірського Ліствичника». У цей список входять 4 книги, доля яких невідома, 3 метою можливого виявлення цих рукописів у майбутньому. 3 28 книг, що дійшли до теперішнього часу, половина (14 книг) зберігається в зібраннях Інституту рукопису Національної бібліотеки України імені В. І. Вернадського: в зібраннях Києво-Печерської лаври (10), Софійського собору (2), Київської духовної 
академії (1) та Микільського монастиря (1). Крім того, рукописи з текстом «Сибірського Ліствичника» $\in$ в зібраннях Росії (5), Румунії (4), Греції (3), Литви (1), Білорусі (1). Висновки. Необхідно провести ретельний комплексний історико-філологічний аналіз найдавніших київських рукописів з текстом «Сибірського Ліствичника». В результаті цього аналізу може підтвердитися висловлена в статті гіпотеза про створення книги в київському монастирі одним із ченців цього монастиря (можливо, виявиться й ім'я цього ченця). У цьому випадку може бути розвінчана усталена в науці думка стосовно того, що автором твору був митрополит Філофей Лещинський. 3 iншого боку, необхідно ретельно досліджувати біографію Філофея Лещинського (київський період його життя). В результаті цього аналізу може підтвердитися гіпотеза про приналежність «Сибірського Ліствичника» митрополитові Філофею.

Ключові слова. Сибірський Ліствичник, Філофей Лещинський, Ліствиця Іоанна Синайського, рукописні зібрання, давньоруська література.

Стаття підготовлена 9 березня 2021 року; подана до друку 16 березня 2021 року. 